\begin{tabular}{|c|c|c|}
\hline & Int.J.Curr.Microbiol.App.Sci (2021) 10(12): 316-321 & \\
\hline & $\begin{array}{l}\text { International Journal of Current Microbiology and Applied Sciences } \\
\text { ISSN: 2319-7706 Volume } 10 \text { Number } 12 \text { (2021) } \\
\text { Journal homepage: http://www.iicmas.com }\end{array}$ & $\$ 0$ \\
\hline $\begin{array}{l}\text { EXCELLENT } \\
\text { PUBLISHERS }\end{array}$ & & \\
\hline
\end{tabular}

\title{
Impact of Soil and Water Conservation Measures on Irrigation Potential and Crop Productivity at Mandakhali Watershed, Maharashtra
}

\author{
S. R. Ullewad ${ }^{1 *}$ and M. R. More ${ }^{2}$ \\ ${ }^{1}$ Department of Ag. Engg., College of Agriculture, Naigaon, Dist Nanded, India \\ ${ }^{2}$ SWCE, College of Agril. Engg. and Technology, VNMKV Parbhani, India
}

*Corresponding author

\section{A B S T R A C T}

Keywords

SWC measures, irrigation potential, crop productivity

\section{Article Info}

Received:

08 November 2021

Accepted:

30 November 2021

Available Online:

10 December 2021
Impact Assessment of soil and water conservation (SWC) measures undertaken at Mandakhali watershed, Parbhani District, Maharashtra. It was carried out during 2017-18to study effect of SWC measures on irrigation potential and crop productivity. Different SWC measures undertaken at Mandakhali watershed were graded bunds, continuous contour trenches, cement nala bunds and farm ponds. Beneficiary farmer's survey was conducted to study the effect of SWC measures on cropping pattern, crop productivity, irrigation facility and area under irrigation. Various SWC measures showed their positive effect on cropping pattern and crop productivity. The area under irrigation was found to be increased by 68.16 per cent after construction of SWC measures at watershed.

\section{Introduction}

Soil and water are the two most important natural resources required for the survival of living things on the Earth. In India rainfall is uneven, erratic and varies from place to place and from year to year. In Maharashtra rainfed agriculture is characterized namely by low productivity, degraded natural resources and wide spread poverty. The factors, which are responsible for the low level of productivity in the state, are obviously soil erosion and low irrigation coverage. Limited irrigation facilities, erratic behaviour of monsoon, constant threat of drought to nearly half of the gross cropped area are the basic factors inhibiting progress of agriculture in the state.

Water is most essential input to agricultural production. With the limited scope of development of irrigation potential, rain water management plays an important role to supplement the surface water for domestic, irrigation and industrial uses. Therefore, efficient conservation and scientific management of harvested water is crucial for 
optimum utilization for crop production. Soil and water conservation structure create temporary storage of water and helping in ground water recharge. With the ever growing population, the need of water is also increasing but the chief source of water i.e. rainfall is almost constant or decreasing day by day. For efficient water management, all the structures need to be evaluated for their effect on the ground water recharge in the watershed (Gore et al., 2000).

Watershed management for rainfed area is an integrated area development approach to promote mixed farming systems under complex, diverse and risk prone environment by adopting suitable combination of crops, and forestry components in consonance with carrying capacities of soils. Reduction in runoff and soil loss and improvement in production have been achieved through proper land use, selection of suitable crops and varieties, crop rotation and cultural practices. (Ranade et al., 1995). The adoption of dry land conservation technologies can increase productivity and profitability of watershed area.

Along with the increased surface and groundwater availability and concomitant private investments also substantially increased in the developed watersheds, resulting in the increased incomes as well as improved livelihoods (Sreedevi et al., 2006, 2008 and Pathak et al., 2007).

Soil and water conservation is a very important aspect of watershed management but in order to realize the highest benefits for the people, the other aspect like socioeconomic situation should not be neglected. Hence impact evaluation of dry land technologies is essential to know an overall effect of soil and water conservation measures on irrigation potential, crop productivity and cropping pattern.

\section{Materials and Methods}

The Soil and Water Conservation Works at Mandakhali watershed Dist. Parbhani were undertaken in 2014-15 by Department of Agriculture, Government of Maharashtra under Jalyukt Shivar Abhiyan. The jurisdiction of Mandakhali watershed encompasses $19^{\circ} 14^{\prime} \mathrm{N}$ latitude and $76^{\circ} 38^{\prime} \mathrm{E}$ longitude at $400 \mathrm{~m}$ from mean sea level. It is located $16 \mathrm{~km}$ towards West from Parbhani city. The total geographical area of watershed is $2167.03 \mathrm{ha}$, out of that 1920 ha area is under cultivation and topography is flat to undulating. The general slope of cultivable land ranges from 1 to 4 per cent while slope of non-cultivable land ranges from 3-15 per cent. The village area consists of soil group deep black cotton soil and receives an average annual rainfall $800 \mathrm{~mm}$.

The survey was conducted for studying the effect of soil and water conservation measures on irrigation potential and crop productivity. In watershed area main Kharif crops grown by farmer were cotton, soybean, green gram, pigeon pea, black gram, sorghum and in Rabi season wheat, gram, rabi jowar, safflower. Where as in summer season very little area was under vegetable and fodder cultivation.

Beneficiary farmer's survey was conducted to assess the impact of SWC measures on study the effect of SWC measures on cropping pattern, crop productivity, irrigation facility and area under irrigation. The data collected from farmers was compared with predevelopment data provided by office of TAO Dist Parbhani.

\section{Results and Discussion}

The impact of soil and water conservation measures on cropping pattern, crop productivity, area under irrigation and irrigation potential was assessed with the help 
of 25 beneficiary framers. The results obtained from the present study are presented as under.

The data with respect to unirrigated and irrigated area during Kharif season is presented in Table1. Table 1 shows that sorghum and black gram was cultivated under rainfed condition and turmeric crop was cultivated under irrigated condition. The productivity of irrigated crops like cotton, soybean, green gram, and pigeon pea was recorded as $21.61,15.50,14.50$ and $10.30 \mathrm{q} / \mathrm{ha}$ which were greater by 66.74, 25.50, 39.42 and 52.59 per cent respectively than the productivity of unirrigated crops.

The data with respect to unirrigated and irrigated area during rabi season is presented in Table 2. Table 2 shows that out of 83.10 ha area, 36.83 ha area was cultivated in rabi season with the crops like wheat, rabi jowar, gram, safflower and vegetables. The gram was the only crop taken under irrigated and unirrigated condition in the season. The productivity of irrigated gram was recorded as $8.50 \mathrm{q} /$ ha which was greater by 54.54 per cent than the unirrigated gram.

The data with respect to unirrigated and irrigated area during summer season is presented in Table 3. Table 3 shows that out of 83.10 ha area, only 4.00 ha area was cultivated in summer season. That was under fodder and different vegetable crops under irrigated condition. The productivity of fodder crops was recorded as $200 \mathrm{q} / \mathrm{ha}$ whereas in case of vegetables the productivity was recorded as 7$8 \mathrm{q} / \mathrm{ha}$.

The data pertaining to productivity of various crops before (pre development) and after construction (Post development) of SWC measures in watershed is presented in Table 4. From Table 4, it is seen that the productivity of all crops grown in different seasons was increased after post development stage of watershed as compared to its pre development stage. The productivity of crops was increased due to adoption of suitable SWC measures and conservation of the moisture in watershed area. It was also observed that after construction of SWC measures, 1.62 ha area was brought under turmeric crop. The productivity of turmeric was recorded as 54.34 q/ha.

The irrigation facilities at post development stage of watershed as compared to itspre development stage is presented in Table 5.

Table.1 Area and productivity of different crops in kharif season

\begin{tabular}{|c|c|c|c|c|c|c|}
\hline \multirow{2}{*}{$\begin{array}{l}\text { Sr. } \\
\text { No. }\end{array}$} & \multirow{2}{*}{$\begin{array}{l}\text { Kharif } \\
\text { crops }\end{array}$} & \multicolumn{2}{|c|}{ Unirrigated } & \multicolumn{2}{|c|}{ Irrigated } & \multirow{2}{*}{$\begin{array}{l}\text { Impact on } \\
\text { productivity } \\
\text { (per cent) }\end{array}$} \\
\hline & & $\begin{array}{l}\text { Area } \\
\text { (ha) }\end{array}$ & $\begin{array}{l}\text { Productivity } \\
\text { (q/ha) }\end{array}$ & $\begin{array}{c}\text { Area } \\
\text { (ha) }\end{array}$ & $\begin{array}{l}\text { Productivity } \\
\text { (q/ha) }\end{array}$ & \\
\hline 1. & Cotton & 10.12 & 12.96 & 32.48 & 21.61 & 66.74 \\
\hline 2. & Soybean & 18.42 & 12.35 & 3.23 & 15.50 & 25.50 \\
\hline 3. & Green Gram & 2.83 & 10.40 & 1.61 & 14.50 & 39.42 \\
\hline 4. & Pigeon pea & 2.44 & 6.75 & 3.64 & 10.30 & 52.59 \\
\hline 5. & Black Gram & 1.21 & 9.50 & --- & --- & --- \\
\hline 6. & Sorghum & 5.47 & 12.40 & --- & --- & --- \\
\hline 7. & Turmeric & --- & --- & 1.62 & 54.34 & --- \\
\hline
\end{tabular}


Table.2 Area and productivity of different crops in rabi season

\begin{tabular}{|c|c|c|c|c|c|c|}
\hline \multirow{2}{*}{$\begin{array}{c}\text { Sr. } \\
\text { No. }\end{array}$} & \multirow{2}{*}{ Rabi crops } & \multicolumn{2}{|c|}{ Unirrigated } & \multicolumn{2}{|c|}{ Irrigated } & $\begin{array}{c}\text { Increase in } \\
\text { productivity } \\
\text { (per cent) }\end{array}$ \\
\cline { 3 - 7 } & & $\begin{array}{c}\text { Area } \\
\text { (ha) }\end{array}$ & $\begin{array}{c}\text { Productivity } \\
\text { (q/ha) }\end{array}$ & $\begin{array}{c}\text { Area } \\
\text { (ha) }\end{array}$ & Productivity(q/ha) & --- \\
\hline 1. & Wheat & --- & --- & 8.50 & 24.70 & --- \\
\hline 2. & Rabi Jowar & 11.13 & 9.50 & --- & --- & 54.54 \\
\hline 3. & Gram & 7.50 & 5.50 & 4.30 & 8.50 & --- \\
\hline 4. & Safflower & 3.40 & 10.50 & --- & --- & --- \\
\hline $\mathbf{5 .}$ & Vegetables & --- & --- & 2.0 & 8.00 & \\
\hline
\end{tabular}

Table.3 Area and productivity of different crops in summer season

\begin{tabular}{|c|c|c|c|}
\hline \multirow{2}{*}{ Sr. No. } & Summer crops & \multicolumn{2}{|c|}{ Irrigated } \\
\cline { 3 - 4 } & & Area (ha) & Productivity(q/ha) \\
\hline 1. & Fodder & 1.50 & 200.00 \\
\hline 2. & Vegetables & 2.50 & $7-8$ \\
\hline & Total & 4.00 & --- \\
\hline
\end{tabular}

Table.4 Impact of SWC measures on productivity of various crops.

\begin{tabular}{|c|c|c|c|c|}
\hline \multirow[t]{2}{*}{ Sr.No. } & \multirow[t]{2}{*}{ Crops } & \multicolumn{2}{|c|}{ Crop productivity (q/ha) } & \multirow{2}{*}{$\begin{array}{l}\text { Increase in crop } \\
\text { productivity }(\%)\end{array}$} \\
\hline & & $\begin{array}{c}\text { Pre development } \\
(2014-15)\end{array}$ & $\begin{array}{c}\text { Post development } \\
(2017-18)\end{array}$ & \\
\hline 1. & Cotton & 13.50 & 21.60 & 60.00 \\
\hline 2. & Soybean & 11.60 & 15.50 & 33.62 \\
\hline 3. & Green gram & 8.50 & 14.50 & 70.58 \\
\hline 4. & Pigeon pea & 7.30 & 10.30 & 41.09 \\
\hline 5. & Black gram & 7.50 & 9.50 & 26.66 \\
\hline 6. & Sorghum & 9.50 & 12.40 & 30.52 \\
\hline 7. & Turmeric & -- & 54.34 & -- \\
\hline 8. & Wheat & 19.70 & 24.70 & 25.38 \\
\hline 9. & Rabi jowar & 7.40 & 9.50 & 28.37 \\
\hline 10. & Gram & 6.25 & 8.50 & 36.00 \\
\hline 11. & Safflower & 7.50 & 10.50 & 40.00 \\
\hline 12. & Vegetables & 5.40 & 8.00 & 48.14 \\
\hline 13. & Fodder & 120.00 & 200.00 & 66.66 \\
\hline
\end{tabular}

Table.5 Irrigation facilities at pre and post development stage of Mandakhali watershed

\begin{tabular}{|c|c|c|c|}
\hline $\begin{array}{c}\text { Sr. } \\
\text { No }\end{array}$ & Particulars & $\begin{array}{c}\text { Pre development } \\
(\mathbf{2 0 1 4 - 1 5 )}\end{array}$ & $\begin{array}{c}\text { Post development } \\
(\mathbf{2 0 1 7 - 1 8})\end{array}$ \\
\hline $\mathbf{1 .}$ & Open wells & 13 & 23 \\
\hline $\mathbf{2 .}$ & Bore wells & 03 & 07 \\
\hline $\mathbf{3 .}$ & Drip sets & 07 & 21 \\
\hline $\mathbf{4 .}$ & Sprinkler sets & -- & 05 \\
\hline $\mathbf{5 .}$ & Lined Farm Ponds & -- & 02 \\
\hline $\mathbf{6 .}$ & Unlined Farm Ponds & -- & 03 \\
\hline
\end{tabular}


Table.6 Area irrigation area under various crops at Pre and Post development of watershed

\begin{tabular}{|c|c|c|c|c|}
\hline \multirow[t]{2}{*}{ Sr.No. } & \multirow[t]{2}{*}{ Crops } & \multicolumn{2}{|c|}{ Area under irrigation (ha) } & \multirow{2}{*}{$\begin{array}{c}\text { Increase in } \\
\text { irrigated area } \\
(\%)\end{array}$} \\
\hline & & $\begin{array}{c}\text { Before development } \\
(2014-15)\end{array}$ & $\begin{array}{c}\text { After development } \\
(2017-18)\end{array}$ & \\
\hline 1. & Cotton & 24.40 & 32.48 & 33.11 \\
\hline 2. & Soybean & --- & 3.23 & --- \\
\hline 3. & Green gram & 1.00 & 1.61 & 61.00 \\
\hline 4. & Pigeon pea & 2.20 & 3.64 & 65.45 \\
\hline 5. & Turmeric & --- & 1.62 & --- \\
\hline 6. & Wheat & 5.30 & 8.50 & 60.37 \\
\hline 7. & Gram & 2.10 & 4.30 & --- \\
\hline 8. & Vegetables & 1.50 & 4.50 & --- \\
\hline 9. & Fodder & --- & 1.50 & --- \\
\hline & Total & 36.50 & 61.38 & 68.16 \\
\hline
\end{tabular}

Data presented in Table 5, revealed that after construction of SWC measures at Mandakhali watershed, numbers of open wells, bore wells and drip sets were increased from 13 to 23,3 to 7 and 7 to 21 respectively. This was happened due to increase in ground water availability in the watershed area. It was observed that after construction of SWC measures in watershed area, farmers dug out three unlined farm ponds and two lined farm ponds for storage of irrigation water. Also farmers have purchased five sprinkler irrigation system sets after development of watershed. It was observed that farmers have shown interest in adoption of micro irrigation systems such as sprinkler and drip because they realized the importance of these systems.

Table 6, shows that the irrigated area under cotton, green gram, pigeon pea, wheat, gram and vegetables were increased at post development stage of watershed. It was also observed that after construction of SWC measures in watershed, 3.23, 1.62 and 1.50 ha area were brought under irrigation of soybean crop, turmeric crop and fodder crops respectively. The total area under irrigation of different crops was increased from 36.50 ha to 61.38 ha at post development stage. Irrigated area of different crops was increased by 68.16 per cent due to adoption of suitable SWC measures in the watershed area.

Due to implementation of the SWC measures at Mandakhali watershed, more land is brought under irrigation. Also due to adoption of various SWC measures there were increase in water availability. Also there was increase in productivity of different crops. As a result of this, total crop production of the farmers was found to be increased as compared to pre development stage of watershed. It resulted in increase in annual income of the farmers of the village. Also the migration percentage of the peoples of village in search of job was reduced to great extent after construction of SWC measures in watershed. Increased income enables a better life in terms of better food, clothes, education, health etc. It was observed that there was overall improvement in economic status of beneficiaries in the watershed area.

Different soil and water conservation measures showed their positive effect on irrigation potential and crop productivity. The area under irrigation was found to be increased by68.16 per cent after development of SWC works. The area was increased under Rabi and summer season crops due to 
availability of irrigation water. The activities of SWC programme was found to be beneficial to the farmers.

\section{References}

Abuj, M. D., Magar P. A., Bombale V. T., Bhutada S. H. and P. R. Bhandari. 2010. Impact of soil and water conservation structures on ground water recharge in Darakwadi watershed. International J. Agriculture Engineering, 3(1): 121-124.

Bombale, V. T., More M. R. and. Mahale D. M.2012. Evaluation of earthen nala bunds for the Konkan region of Maharashtra state. International Journal of Agricultural Engineering, 5(1): 25-27.

Deshmukh, A. P. 2010. Evaluation of watershed development programme implemented in Attharwadi watershed. International J. of Agricultural Engineering, 3(2): 205 -208

Gore, K. P., Pendke, M. S. and Jallawar, D. N. 2000. Impact assessment of soil and water conservation structure in Darakwadi watershed, Karnataka. J. agric. Sci., 13(3): 676- 681.

Mandal, Biswjit, Loganandhan, N. and Reddy, K. K. 2006. Impact evaluation of watershed development project on socioeconomic indicators $-\mathrm{A}$ case study. Indian J. Soil. Cons., 34 (1): 69-74.

Pathak P, Wani S P, Sudi R, Chourasia A K, Singh S N and Kesava Rao A V R. 2007. Rural prosperity through integrated watershed management: A case study of Gokulpura-Goverdhanapura in eastern
Rajasthan, India: International Crops Research Institute for the Semi Arid Tropics. 52 pp.

Ranade, D. H., Chourasia, M. C., Gupta, R. K., Upadhyay, M. S. and Nema, R. S. 1995. Integrated approach for increased agricultural productivity in dry land areas of vertisols. Indian J. Soil. Cons., 23 (1): 30-33

Sreedevi T K, Wani S P, Sudi R, Patel M S, Jayesh T, Singh S N and Tushaar Shah. 2006. On-site and off-site impact of watershed development: A case study of Rajsamadhiyala, Gujarat, India. Global Theme on Agroecosystems Report no. 20, Patancheru 502324, Andhra Pradesh, India: International Crops Research Institute for the Semi Arid Tropics. 48 pp.

Sreedevi T K, Wani S P, Sudi Raghavendra Rao, Harsha Vardhan Deshmukhi, Singh S N and Marcella D'souza. 2008. Impact of Watershed Development in Low Rainfall Region of Maharashtra: A Case Study of Shekta Watershed. Global Theme on Agroecosystems Report no. xx Patancheru 502 324, Andhra Pradesh, India; International Crops Research Institute for Semi-Arid Tropics.

Tilekar, S. N., Hange D. S., Shendge P. N., Kalhapure S. P. and A. J. Amale. 2009. Economic Evaluation of Bahirwadi Watershed in Ahmednagar District of Maharashtra - A Case Study for Replication in Potential Areas. Agricultural Economics Research Review, Vol. 22: 415-422.

\section{How to cite this article:}

Ullewad, S. R. and More, M. R. 2021. Impact of Soil and Water Conservation Measures on Irrigation Potential and Crop Productivity at Mandakhali Watershed, Maharashtra. Int.J.Curr.Microbiol.App.Sci. 10(12): 316-321. doi: https://doi.org/10.20546/ijcmas.2021.1012.037 